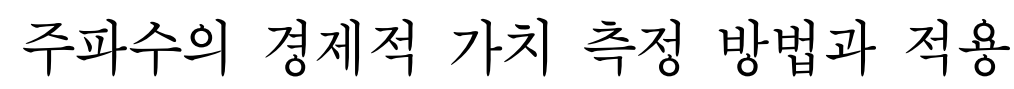

\title{
Measurement and Application of the Economic Value of Radio Spectrum
}

\author{
변 희 섭. 연 권 흠* 김 기 원** \\ Hee Sub Byun $\cdot$ Kwon-Hum Yeon* $\cdot$ Ki Won Kim** \\ 요 약
}

국가자원인 주파수의 효율적 활용을 위한 정책 대안으로 경제성에 입각한 시장 중심의 관리 체계의 도입이 적극적으 로 검토되고 있다. 하지만, 국내에서 이동통신, 주파수 공용통신을 제외한 대부분 용도의 주파수에 대해 심사할당이 이루 어져 경제성을 인식하기 위한 사례가 부족한 실정이다. 이러한 정책적 수요에 대응하기 위해, 본 연구는 국내 주요 용도 별 주파수의 경제성 평가 대안을 제시한다. 먼저, 평가 대안으로 경매, 이익 접근, 벤치마크 접근, 기회비용 접근, 생산함 수 접근 등이 적용 가능할 것으로 판단된다. 주파수의 경제적 가치 측정 방식은 경쟁적 수요, 제공 서비스의 수, 과거 이용대가 부과 사례, 주파수 활용 이외의 대안 등 용도별 특성에 따라 달라질 수 있음을 제안한다. 본 연구의 결과는 주파수의 경제성 평가를 객관화·체계화하는데 기여함으로써 관련 정책 수립의 기초자료로 활용될 것으로 기대한다.

\section{Abstract}

A market-based management system based on economic value is being actively considered as a policy alternative for the efficient use of radio spectrum. However, there exist insufficient cases for evaluating the economic value of radio spectrum in Korea. To address these policy demands, this study proposes alternatives to evaluate the economic value of radio spectrum. The auction, profit approach, benchmark approach, opportunity-cost approach, and production function approach can be considered as alternatives. Moreover, the applications of radio spectrum evaluation may vary depending on competitive demand, the number of services provided, cases of past-usage charges, and the existence of least-cost alternatives. The results of this study are therefore expected to be used as basic data for the establishment of related policies by contributing to objectification and systematization of the economic evaluation of radio spectrum.

Key words: Radio Spectrum Policy, Market-Based Management, Economic Value, Evaluation Methodology

\section{I. 서 론}

국가자원인 주파수(radio spectrum)의 수요가 높지 않았
던 과거에는 '간섭 방지'를 정책 목표로 설정하였다. 하지 만 4차 산업혁명 등으로 인한 무선 네트워크의 활용 범위 가 확장되고 있는 현재는 높은 수요로 인해 '효율적 자원

\footnotetext{
「이 논문은 2020년도 정부(과학기술정보통신부)의 재원으로 정보통신기획평가원의 지원(No.2017-0-00109, 전파자원 선순환을 위한 주파수 분석 기 술 개발)을 받아 수행된 연구이며, 이러한 지원에 의해 작성된 변희섭 외 (2020) ${ }^{[1]}$ 을 보완하여 작성함. 또한, 이 논문은 2020년도 한림대학교 교비연 구비(HRF-202011-005)에 의하여 연구되었음. 한림대학교 경영대학 금융재무학과(Dept. of Finance, College of Business, Hallym University) *세종기술경제연구소(Sejong Economic Research Institute on Technology)

**한국방송통신전파진흥원 전파자원개발팀(Spectrum Refarming Team, Korea Communications Agency)

- Manuscript received November 16, 2020 ; Revised December 7, 2020 ; Accepted December 19, 2020. (ID No. 20201116-007S)

· Corresponding Author: Hee Sub Byun (e-mail: heesbyun@hallym.ac.kr)
} 
배분'으로 정책 목표가 전환되고 있다. 이러한 관점에서 '시장원리'에 입각한 정책 및 제도의 도입이 적극적으로 검토되고 있다. '시장원리'에 입각한 주파수 관리 정책은 경제적 효율성의 극대화를 추구함으로써 이행될 수 있다. 2019년 11월 입법 예고된 전파법[2]에서는 기존 주파수 이 용제도를 면허제로 통합하고, 대부분의 주파수 면허에 대 해 면허료(license fee)를 부과하는 방안이 검토되고 있다. 면허료 부과는 경제성에 입각한 시장 중심(market-based) 주파수 관리에 기초적 수단으로 인식될 수 있으며, 필히 용도별 주파수의 경제성을 사전에 인식하는 작업이 선행 되어야 한다.

국내에서 주파수의 할당1)은 심사할당과 대가할당으로 구분되어 이루어져 왔다. 그간 이동통신, 주파수 공용통 신 용도 주파수에 대해서만 대가할당이 이루어졌으며, 여 타 용도의 주파수에 대해서는 심사할당이 적용되어 왔다. 심사할당의 경우, 경제적 가치에 기초한 이용대가가 부과 된 사례가 존재치 않는다. 뿐만 아니라, 이용대가가 부과 되었던 여타 용도의 주파수와 사업적, 기술적 특성이 상 이하다. 따라서 고유의 특성을 고려한 별도의 경제성 평 가 대안을 검토 - 도출할 필요가 제기된다. 이러한 국내 현실을 감안할 때, 시장 중심의 주파수 관리로의 정책 전 환 이전 주파수의 경제성을 평가하기 위한 다양한 대안 들을 모색해야 할 필요성이 가중된다.

주파수의 경제성 평가 대안으로 (i) 경매, (ii) 이익 접 근, (iii) 기회비용 접근, (iv) 생산함수 접근, (v) 벤치마크 접근 등이 제안되고 있다. 하지만 주파수는 용도별 활용 특성이 상이하기 때문에 위의 방법론을 모두 일관적으로 적용하는데 어려움이 있다. 따라서 최적 대안을 사전에 선별하여 적용 가능성을 제시하는 것은 잠재적 행정비용 을 축소하고, 정책적 유연성을 담보하기 위해 필요하다. 예를 들어, 단일 사업자가 존재하는 서비스 용도의 주파 수의 경우 경쟁적 수요에 기초한 경매가 어려우며, 동일 사업자가 여러 서비스를 제공하는 경우, 단일 재무제표에 기초한 이익접근의 적용이 적합하지 않다.

본 연구는 국내 용도별 주파수의 경제성 평가 대안과
적용 방향을 제안함으로써 정책적 시사점을 제공한다. 연 구는 3 단계로 (i) 주파수의 경제성 평가 대안 탐색, (ii) 국 내 주요 용도별 주파수 활용 서비스의 특성 파악, (iii) 용 도별 주파수의 경제성 평가 최적 대안 제안의 순서로 이 루어진다. '주파수의 경제성 평가 대안 탐색'에 관련하여 각 방법론의 이론적 배경과 실증적 적용에 있어 필요로 하는 제약조건을 제시한다. '국내 주요 용도별 주파수 활 용 서비스의 특성 파악'에 관련하여 먼저, 사업용 주파수 와 비사업용 주파수로 구분하고, 이를 또 다시 서비스의 유형에 따라 재분류하여 주파수의 활용 현황과 특성을 도출한다. '용도별 주파수의 경제성 평가 최적 대안 제안' 에 관련하여 앞서 도출한 방법론 적용의 제약조건과 용 도별 주파수의 활용 특성을 종합적으로 검토하여, 적합한 대안을 탐색하는 과정을 제안한다. 최종적으로 이러한 과 정을 적용하여, 현재 국내에서 할당된 용도별 주파수의 경제성 평가의 대안들을 제시한다.

본 연구의 결과는 정책적으로 효율적인 국가자원 관리 라는 목표를 달성하는데 기여할 것으로 예상된다. 경제성 에 입각한 주파수 관리의 중요성은 충분히 인식되고 있 지만, 경제적 가치(즉, 이용대가)의 적정성에 대한 논쟁이 제기될 수 있다, 특히, 주파수의 용도가 다양하다는 측면 에서 하나의 정형화된 방법론만으로는 평가가 용이하지 않기 때문에 다양한 방법론의 현실적 적용 가능성을 검 토하는 작업이 더욱 적극적으로 요구된다. 따라서 누구나 쉽게 납득할 수 있는 객관적인 대안을 통해 경제성이 합 리적으로 평가되어야 하며, 본 연구는 이러한 정책 목표 를 달성하기 위한 기초자료로 활용이 가능할 것으로 기 대한다.

본 연구는 다음과 구성된다. II 장에서는 현실적 활용 이 가능한 주파수의 경제성 평가 대안들을 제시한다. III 장에서는 국내 주요 용도별 주파수의 활용 현황과 특성 을 파악한다. IV 장에서는 II 장과 III장의 내용을 종합하 며, 용도별 주파수의 경제성 평가의 대안들을 제시한다. 마지막으로 $\mathrm{V}$ 장에서는 본 연구의 결론과 시사점을 논의 한다.

1) 할당 이외에도 사용승인과 지정의 관리 절차가 존재한다. 사용승인은 국방 · 외교 등의 목적 또는 국제적· 국가적 행사 등을 위해 주파수 이용을 승인하는 것으로 승인 후 무선국의 허가나 신고절차가 없다. 지정은 할당-사용승인 이외의 무선국에 대해 이용 주파수를 정해주는 것으로 무선국 의 개설과 허가·신고 시 지정한다. 지정과 사용승인 주파수는 할당대가를 부과하지 않고 양도·임대가 허용되지 않는다. 


\section{II. 주파수의 경제성 평가 대안2)}

경제성 평가 대안을 제시하기에 앞서 주파수의 특성을 파악하여 평가의 당위성을 확인한다. 주파수는 경합성, 희소성과 무형자산이라는 특성을 갖는다3). 더불어 기술 진보에 따라 활용가치가 변화하며, 보편적 서비스인 통신 산업의 필수적 생산요소로 활용된다. 이러한 주파수의 특 성은 경제성에 기초한 관리를 요구한다.

주파수는 상호 간섭을 막기 위해 대개 특정 활용주체 에게 배타적 사용권을 부여한다(경합성). 이러한 특성과 효율적 자원 배분이라는 시장 중심의 주파수 관리 정책 의 목적을 동시에 고려할 때, 경제성을 극대화할 수 있는 주체에게 할당되는 것이 적절하다. 주파수는 희소한 국가 자원으로 공급량이 사전에 제한된다(희소성). 이러한 특 성은 여타 경제적 재화나 서비스와 달리 경쟁적 시장을 전제로 시장기능에 의해 가격(경제적 가치)이 결정되기 어려움을 시사한다. 따라서 주파수 관리자는 경제성을 사 전에 평가. 인식하여 효율적 배분을 위해 활용해야 할 것이다. 무형자산인 주파수는 유형자산과 달리 활용에 따 라 그 가치가 감소하지 않는다. 오히려 신기술 도입에 연 계하여 가치가 증가할 수도 있다. 이 때문에 효율적 회수 및 재배치가 필요하며, 이러한 과정에는 경제성이 고려되 어야 한다.

한편, 주파수는 기술 진보 또는 혁신에 따라 현재 용도 가 아닌 타 용도로의 전환이 가능하므로 수요가 변화될 수 있다. 제한된 공급 하에서 수요의 변화는 해당 자원의 가치(가격)를 변화시킬 수 있다. 즉, 주파수의 경제성은 변화한다. 이러한 가변성을 고려하여, 주기적인 주파수의 경제성 평가가 필요하다. 마지막으로, 주파수는 필수재로 인식되는 통신 서비스의 핵심적 생산요소로 자원 고유한 가치뿐만 아니라, 여타 산업 분야에 미치는 파급효과 (spillover effect)가 내재된다. 이 때문에 사회 전반의 후생 (social welfare)을 고려한 주파수의 관리 정책이 요구되며, 이는 경제적 가치 평가의 논리와 일맥상통한다.

\section{2-1 경매(Auction)}

경매는 경매 참여자가 제시하는 지불의사(willingness to pay)에 기초하여 주파수의 경제성을 추정하는 방법론 이다. 이는 경매 참여자가 주파수를 활용해서 얻을 수 있 는 경제적 편익과 지불할 수 있는 비용을 사전적으로 고 려하여 합리적인 수준의 매수 가격(bidding price)을 제시 함을 전제한다. 즉, 경매 참여자의 합리성과 시장 효율성 을 가정한다.

경매는 참여자의 수, 승자의 저주(winner's curse) 등과 같은 제약이 존재하기 때문에 효율적인 설계가 요구된다 [4]. 주파수 경매의 설계에는 입찰의 공개 여부, 횟수와 연 속성 여부 등이 고려된다. 또한 주파수 경매 시 최저경쟁 가격(reserve price)의 적정한 설정도 필요하다. 특히, 최저 경쟁가격은 주파수 관리자(regulator)가 설정하기 때문에 해당 경매의 정책 목표를 내재화하는 수단으로 고려될 수 있다. 관련하여, 비교적 높은 최저경쟁가격이 설정되 는 경우 시장의 진입장벽(entry barrier)을 형성시켜 자원 배분을 왜곡시킬 우려가 제기될 수 있다. 반면, 낮은 경우 자격이 없는 잠재적 수요자의 진입을 야기함으로써 자원 의 비효율적 활용의 문제가 발생할 수 있다.

주파수 경매는 경제성을 인식할 수 있는 효율적 수단 이지만, 경쟁적 수요가 존재하는 경우에만 적용이 가능하 다. 그렇지 않은 경우, 경매 참여자의 진정한 지불의사, 즉, 경제성 발견이 어렵다. 다른 관점에서 경매를 실시하 더라도, 최소 수준의 경제성을 의미하는 최저경쟁가격을 추정해야 하므로 또 다른 경제성 평가 대안의 활용이 요 구된다.

\section{2-2 이익접근(Income Approach)}

이익접근은 주파수를 활용하는 주체의 경제적 이익을 기반으로 경제성을 추정하는 방식이며, 생산요소인 주파 수의 금전적 활용가치에 주목한다. 이는 기업재무(corpo-

2) 본 연구가 제안한 방법론 이외에 사회후생접근, 산업연관분석 등을 통한 경제성 평가도 가능하다. 사회후생접근은 주파수 활용 주체의 수요와 공급 함수를 추정하고, 할당량 변화에 기인하는 소비자 잉여(consumer surplus)와 생산자 잉여(supplier surplus)의 변화를 기초로 경제성을 추정하는 방법이 다. 산업연관분석은 주파수 유관 산업(전파산업)을 획정하고, 동 산업으로부터 기대되는 파급효과(spillover effect)를 주파수의 경제성으로 의제한다. $3)$ 주파수의 특성에 대한 논의는 변희섭 외 $(2017)^{[3]}$ 을 참고하여 작성하였다. 
rate finance) 분야에서 사업성 평가에 흔히 활용되는 현금 흐름 할인법(discounted cash flow)의 응용 사례로 이해될 수 있다. 동 방법론은 직관적으로 이해가 용이할 뿐만 아 니라, 공개된 자료를 활용하기 때문에 객관성이 담보된다 는 장점을 갖는다.

이익접근은 식 (1)에 의해 추정될 수 있다. 현금흐름 (cash flow)은 주파수를 활용한 서비스로부터 창출되는 경 제적 이익을 의미한다. $r$ 는 할인율이며, 미래 발생할 경제 적 이익을 현재가치로 변환하는데 활용된다. $n$ 은 주파수 의 할당기간을 의미하며, 기술적 기여도(TC, technical contribution)는 주파수가 해당 서비스의 경제적 이익 창출 에 기여하는 수준을 의미한다.

$$
\text { Spectrum value }=\sum_{t=1}^{n} \frac{\text { Cash flow }}{(1+r)^{t}} * T C
$$

이익접근의 체계 및 절차를 재무제표 항목을 활용하여 세분화하면, 매출액에서 매출원가, 판매비 및 관리비와 법 인세 비용 등 영업활동에 수반되는 비용 요인을 차감하여 세후 영업이익을 계산한다. 이 값에 비현금유출 요인인 감가상각비를 더하고, 설비투자에 수반되는 자본지출(capital expenditure)과 단기투자를 의미하는 운전자본(working capital)의 변화를 차감한다. 더불어, 향후 보유 설비 를 매도함을 전제로 회수될 금액을 더하여 현금흐름을 추 정한다. 현금흐름에 현가계수(discounted factor)를 곱하여 현재가치의 추정이 가능하며, 투자기간(즉, 주파수의 할당 기간)동안 창출될 것으로 기대되는 현재가치를 합한 금액 이 순현재가치(net present value)4)로 표현될 수 있다. 마지 막으로, 순현재가치에 주파수의 기술적 기여도5)를 곱하 여 최종적인 주파수의 경제성을 추정할 수 있다.

이익접근의 적용은 프로젝트(project) 단위의 평가를 가 정한다. 따라서 특정 사업자가 두 개 이상의 서비스를 제 공하는 경우, 서비스들로부터 발생하는 영업이익, 설비투
자비용 등을 구분하여 각기 투입된 주파수의 경제성을 평가해야 한다. 하지만 사업자의 단일 재무제표를 서비스 별로 구분하는 것은 현실적으로 어렵다6). 따라서 한 개의 서비스만을 제공하는 사업자에 대해서만 재무제표 항목 을 활용한 이익접근이 용이할 것으로 판단된다.

\section{2-3 벤치마크접근(Benchmark Approach)}

벤치마크접근은 기존의 주파수 할당가격 또는 거래가 격을 기초로 주파수의 경제성을 추정하는 방식이다. 따라 서 기존에 형성된 거래가격의 정보력을 신뢰함을 전제한 다. 이는 크게 두 가지 방식으로 적용되는데, 시계열(timeseries)접근과 횡단면(cross-sectional)접근이다. 시계열 접 근은 해당 국가의 과거 주파수 할당가격을 참고하는 방 식이다. 횡단면 접근은 여타 국가의 유사 대역 할당 가격 을 참고하는 방식이다. 동 방법론은 평균 벤치마킹(benchmarking using averaging method approach)와 회귀분석(regression) 방식으로 적용될 수 있다. 평균 벤치마킹은 일반 적으로 인구 1 인 기준 주파수 $\mathrm{MHz}$ 당 평균 가격을 설정한 다. 회귀분석은 주파수의 할당가격에 영향을 미칠 수 있 는 다양한 요인(변수)을 사전에 선정하고, 이를 바탕으로 모형화(modeling)를 통해 예상되는 가격을 추정한다 ${ }^{[5]}$.

주파수의 경제성은 시장여건, 제공 가능 서비스의 종 류, 할당 시기, 규제의 강도 등에 의존하므로, 오로지 과 거 사례만을 참고하는 것은 현실성을 약화시킬 수 있다. 특히, 주파수를 활용한 통신기술이 신속하게 발전하고 있 다는 점은 이러한 우려를 가중시킨다. 무엇보다, 참고할 만한 거래 자료가 존재해야 하는데, 국내는 물론이거니와 여타 국가의 사례도 쉽게 확인되지 않는 용도의 주파수 의 경우에는 동 방법론의 적용이 어렵다.

\section{2-4 기회비용접근(Opportunity Cost Approach)}

기회비용접근 ${ }^{[6][7]}$ 은 영국의 $\operatorname{AIP}($ administrative incentive

4) 주파수를 최초로 할당받는 서비스의 경우, 초기 설비투자(기지국 설치 등)에 수반되는 비용을 현재가치에서 차감하여 순현재가치를 추정해야 할 것이다.

5) 기술적 기여도는 현행 전파법 시행령의 할당대가 추정에 있어 활용되는 매출액에 대한 비중(3\%)과 유사한 개념으로 이해될 수 있다고 하지만, 정확한 의미를 따지면, 둘 간의 차이가 존재한다. 기술적 기여도는 '이익'에 기초한 현금흐름에 대한 주파수의 기여율을 의미하는 반면, 전파법 시행령은 ‘수익'에 기초한 매출액에 대한 주파수의 기여율을 의미하기 때문이다.

6) 물론, 정부에 보고되는 별도의 보고서 등을 통해 서비스별 재무제표 항목의 구분이 부분적으로 가능하다. 하지만, 이는 정책 수립 및 이행 목적으로 활용되므로 대중에 공개되지 않아 객관적 활용이 어렵다. 
pricing) 체계 하에서 제안된 주파수의 경제성 평가 방법 론의 하나이다. 동 방법론은 하나의 생산요소인 주파수의 감소로 인해 여타 투입물의 규모를 증가시켜야 한다면, 이에 기인하는 한계가치(marginal value)의 변화를 주파수 의 경제성으로 인식하는 방식이다. 이론적으로 사업자는 생산 효율성(productive efficiency)의 극대화를 위해 가장 낮은 비용으로 생산요소를 투입되어야 한다. 따라서 특정 생산요소를 활용하지 못하여 다른 생산요소를 투입해야 할 경우, 사업자는 비용을 최소화하는 대안을 최적으로 간주할 것이다. 이러한 비용은 기존 생산요소에 내재된 경제성으로 평가될 수 있다. 구체적으로, 사업자가 주파 수를 활용하지 못할 경우, 선택할 수 있는 대안들을 도출 하고, 비용이 가장 적게 드는 대안의 한계가치를 추정한 다. 기회비용은 (1) 신규 설비투자, (2) 또 다른 서비스로 의 전환, (3) 대역 이동, (4) 신기술의 활용 등 네 가지 접 근을 통해 추정될 수 있다(표 1).

표 1. 주파수의 경제성 평가 대안의 제약조건

Table 1. Constraints of alternatives for estimating the spectrum value.

\begin{tabular}{|c|l|}
\hline Alternatives & \multicolumn{1}{c|}{ Constraints } \\
\hline Auction & $\begin{array}{l}\text { - Presence of competitive demands } \\
\text { - Sophisticated auction design } \\
\text { - Estimation of the reserve price }\end{array}$ \\
\hline $\begin{array}{c}\text { Income } \\
\text { approach }\end{array}$ & $\begin{array}{l}\text { - Single service delivery } \\
\text { Presence of separate financial statements by } \\
\text { service }\end{array}$ \\
\hline $\begin{array}{c}\text { Benchmark } \\
\text { approach }\end{array}$ & $\begin{array}{l}\text { - Presence of transaction data } \\
\text { Realistic correction in consideration of chan- } \\
\text { ges in market conditions }\end{array}$ \\
\hline $\begin{array}{c}\text { Opportunity } \\
\text { cost approach }\end{array}$ & $\begin{array}{l}\text { Presence of alternatives to spectrum utiliza- } \\
\text { tion }\end{array}$ \\
\hline $\begin{array}{c}\text { Justification of opportunity costs } \\
\text { Production } \\
\text { function } \\
\text { approach }\end{array}$ & $\begin{array}{l}\text { Sufficient data to estimate the production } \\
\text { function } \\
\text { Justification of the selection of alternative } \\
\text { production factors }\end{array}$ \\
\hline
\end{tabular}

기회비용접근은 명확한 경제이론에 의해 뒷받침된다 는 점에서 이론적 당위성이 높다는 장점을 있다. 그러나, 기회비용의 추정에 있어 설비투자비용, 기술적 효율성, 주파수의 사용조건 등 활용 주체의 내부 자료의 접근이 선행되어야 하는 점이 제약으로 작용할 수 있다. 무엇보 다, 기회비용으로 인식될만한 대안을 도출해야 하는데, 이 과정에서 추정 주체의 자의성이 개입될 가능성이 존 재한다. 따라서 누구나 객관적으로 인식할 수 있는 대안 의 활용이 필요하다.

\section{2-5 생산함수접근(Production Function Approach)}

생산함수접근은 기회비용접근과 유사한 논리로 두 생 산요소 간 한계 생산성(marginal productivity)을 비교하여 주파수의 경제성을 추정한다 ${ }^{[8]}$. 즉, 생산요소 간 대체성을 전제한다. 구체적으로 주파수의 추가 활용에 따른 생산성 증가 효과(한계 생산성)는 여타 생산요소(노동, 자본 등) 의 효과와 일치해야 한다. 이를 전제로 주파수의 경제성 은 여타 생산요소의 가격(투입비용), 투입량, 산출물에 대 한 기여도와 주파수의 투입량, 산출물에 대한 기여도의 조합을 통해 평가될 수 있다.

동 방법론을 구현하기 위해서 생산함수를 실증적 추정 으로 추정해야 하므로 풍부한 자료의 접근과 구축 방안 이 마련되어야 한다. 그래야만 통계적 추론의 신뢰성을 담보할 수 있다. 또한 주파수의 특정 생산요소와의 대체 관계를 사전에 결정해야 하므로, 연구자의 자의성을 완벽 히 배제할 수 없다는 제약도 내재한다.

\section{III. 국내 주요 용도별 주파수의 활용 현황7)8)}

\section{3-1 전기통신사업용9)}

전기통신사업용 주파수의 주요 용도로 이동통신, 주파 수공용통신, 무선호출, 무선데이터, 위성사업 등이 있다. 이동통신 용도 주파수는 이동통신 3개 기업(SK텔레콤,

7) 동 장의 내용은 한국방송통신전파진흥원의 내부 자료에 기초하여 작성하였다.

8) 주파수의 용도별 분류는 대한민국 주파수 분배표 및 주파수 지정관리 지침(2019.6월) 상 용도 분류기준에 기초한다.

9) 전기통신사업용, 자가통신용, 비면허 용도 이외 방송과 사용승인 주파수도 존재한다. 방송 용도는 현재 할당대가가 부과되고 있지 않다. 다만 방송 중계용이나 위성 중계용 주파수에 대해 전파사용료가 부과된다. 미국의 경우, 방송 용도 주파수도 이동통신 용도와 마찬가지로 할당대가를 부과하 
THE JOURNAL OF KOREAN INSTITUTE OF ELECTROMAGNETIC ENGINEERING AND SCIENCE. vol. 32, no. 1, January. 2021.

$\mathrm{KT}, \mathrm{LGU}+$ )이 $800 \mathrm{MHz}-3.7 \mathrm{GHz}$ 대역, $28 \mathrm{GHz}$ 대역에서 총 3,147 MHz폭을 이용하고 있다.10) 4G/LTE(Long Term Evolution) 주파수는 세 차례 경매(2011년, 2013년, 2016 년), $5 \mathrm{G}$ 는 한 차례(2018년) 경매를 통해 공급되었으며, $2 \mathrm{G}$ 및 $3 \mathrm{G}$ 주파수는 정부 산정으로 대가할당이 이루어졌다.

주파수 공용통신 용도 주파수는 단일 사업자인 케이티 파워텔이 $811 \sim 813 / 856 \sim 858 \mathrm{MHz}$ 대역에서 총 $4 \mathrm{MHz}$ 폭 을 이용 중이다. 기존 서비스를 MVNO(mobile virtual network operator) LTE-PTT(push-to-talk)로 전환함에 따라 2017년 12월 $6 \mathrm{MHz}$ 폭을 반납했다. 최근(2019년 6월) 이용 기간이 만료되어 재할당되며, 심사할당에서 대가할당으 로 전환되었다. 대가할당에는 전파법 시행령에 기초한 정 부 산정이 적용되었다.

무선데이터통신 용도 주파수는 단일 사업자인 에어미 디어가 898.00625-898.64375 MHz, 938.00625-938.64375 $\mathrm{MHz}$ 대역에서 총 $1.275 \mathrm{MHz}$ 폭을 이용하고 있다. 증권거 래 등 기존 서비스 외에 버스관제, 산업설비 원격제어 등 의 서비스에 활용되고 있다. 최근(2019년 6월) 과거와 같이 이용대가 없는 심사할당 방식으로 재할당이 이루어졌다.

무선호출 용도 주파수는 단일 사업자인 서울이동통신 이 318.1375-319.1375 MHz, 923.55625-924.05625 MHz 대역에서 총 $1.5 \mathrm{MHz}$ 폭을 이용 중이다. 기존 무선호출 서 비스 외에 위치기반, 원격관제 등 $\mathrm{M} 2 \mathrm{M}$ (machine to machine) 서비스에 활용되고 있다. 무선데이터 용도 주파수 와 동일하게 최근(2019년 6월) 심사할당 방식으로 재할당 되었다.

통신 및 방송중계 용도 주파수는 이동통신 및 방송 사 업자가 활용한다. 대표적으로 국간중계(microwave, $\mathrm{M} / \mathrm{W}$ ) 서비스에 활용되고 있으며, $1.7-86 \mathrm{GHz}$ 범위의 16 개 대 역에서 총 7,028 MHz폭이 활용되고 있다. 해당 용도의 주 파수는 이용대가가 없으며, 전파사용료가 부과되고 있다.
표 2. 전기통신사업용 주파수의 활용 특성

Table 2. Application characteristics of spectrums for telecommunications business.

\begin{tabular}{|c|c|c|c|}
\hline Usage & Utilization entity & Bandwidth & Cost of use \\
\hline $\begin{array}{c}\text { Mobile } \\
\text { communication }\end{array}$ & SKT, KT, LGU+ & $3,090 \mathrm{MHz}$ & Charged \\
\hline $\begin{array}{c}\text { Trunked radio } \\
\text { system }\end{array}$ & KT powertel & $4 \mathrm{MHz}$ & Charged \\
\hline $\begin{array}{c}\text { Wireless data } \\
\text { communication }\end{array}$ & Airmedia & $1.275 \mathrm{MHz}$ & Not charged \\
\hline Radio paging & Seoul mobile telecom & $1.5 \mathrm{MHz}$ & Not charged \\
\hline $\begin{array}{c}\text { Microwave } \\
\text { relay service }\end{array}$ & $\begin{array}{c}\text { Mobile } \\
\text { communication and } \\
\text { broadcasting service } \\
\text { provider }\end{array}$ & $7,028 \mathrm{MHz}$ & Not charged \\
\hline Satellite & $\begin{array}{c}\text { KT sat, } \\
\text { LGU+, Inmarsat, } \\
\text { GMPCS }\end{array}$ & $11,000 \mathrm{MHz}$ & Not charged \\
\hline
\end{tabular}

다만, 일부 이동통신 중계용에는 전파사용료가 부과되고 있지 않다.11)

위성 서비스 용도 주파수는 케이티샛이 최근 전국 위 성서비스의 제공을 위해 11.7-14.8 GHz대역 내 총 1,600 $\mathrm{MHz}$ 폭을 심사할당 받아 사용 중이며, 기타 $\mathrm{LGU}+$ 와 인마 새트, GMPCS(global mobile personal communications by satellite)가 유사한 서비스를 제공하고 있다(표 2).

\section{3-2 자가통신 및 비면허}

자가통신용 주파수는 간이무전기, 레이다, 해상무선통 신, 공공재난망 등에 활용된다. 간이무전기는 국가기관, 국영기업체, 법인, 단체, 개인 사업자 등이 간단한 업무연 락용 무전기로 $146 \mathrm{MHz}, 222 \mathrm{MHz}, 423 \mathrm{MHz} 444 \mathrm{MHz}$ 대 역을 이용하고 있다. 세부적으로 $146 \mathrm{MHz}, 222 \mathrm{MHz}, 422$

고 있으며, 영국과 호주도 관리비용 성격의 전파사용료를 납부하도록 설정되어 있다. 하지만 국내에서는 방송발전기금 납부로 인한 이중부과 견해 와 방송의 공익성 등을 이유로 할당대가가 면제되고 있는 실정이다. 따라서 향후 면허제 도입 시 방송 용도 주파수에 대한 면허료가 책정되더라도 실제 대가 부과에는 정책적 판단이 필요할 것으로 판단된다. 한편, 사용승인 주파수의 경우, 군과 국가기관 등이 국방 및 보안 상의 목적으로 사용하 고 있어 할당대가가 부과되지 않는다. 사용승인 주파수의 이용현황은 보안자료로서 연구를 위한 획득이나 활용이 불가하다. 이상의 이유로 방송과 사용승인 주파수는 본 연구의 분석대상에서 제외한다.

10) 보호대역 등 $274 \mathrm{MHz}$ 폭은 미할당.

11) 현행 전파법 제67조에서는 전파사용료의 감면 요건을 제시하고 있다. 관련하여, 대가에 의한 주파수할당(전파법 제11조)에 따라 전기통신역무를 제공하는 무선국(제67조 제5항)에 대해 전파사용료가 감면될 수 있음을 규정하고 있다. 
$\mathrm{MHz}, 444 \mathrm{MHz}$ 대역에서 채널 간격 $12.5 \mathrm{kHz}$ 폭으로 총 221 개 채널을 지정받아 사용 중이다. 주로 건설현장, 가 스배달, 경비업체, 대형 할인점 등 소규모 사업장에서 상 호 혼신을 용인하는 조건으로 약 40 만국을 이용 중에 있 다. 해당 주파수는 할당이 아닌 지정 방식으로 이용하는 주파수이므로 할당대가가 부과되지 않고 전파사용료만 부과되고 있다(표 3).

레이다 용도 주파수는 대부분 군 및 공공기관에서 탐 지, 함정, 항공항행, 무선표정, 기상레이다용으로 1,215 MHz-36 GHz 대역에서 약 $7 \mathrm{GHz}$ 폭을 이용하고 있다. 해 상무선통신 용도 주파수는 $\mathrm{HF}$ (high frequency) · VHf(very high frequency) $\operatorname{UHF}$ (ultra high frequency)대역에서 단 파 - 중단파대 무선전화, GMDSs(global maritime distress and safety system, 해상조난안전), 해상이동업무 등에 사 용된다. 이 중 $3 \cdot 9 \mathrm{GHz}$ 대역은 선박레이다 등 항해정보 제공용 무선표지설비(radar beacon), 8·9·18·19 GHz 대역은 해상교통관제(vessel traffic service) 용도로 사용 중에 있다. 공공재난망은 공공기관 등이 공공업무용, 행 정업무용, 재난구조용 등의 용도로 $\mathrm{HF} \cdot \mathrm{VHF} \cdot \mathrm{UHF}$ 대역 전반이 활용된다.

비면허(신고하지 아니하고 개설할 수 있는 무선국용 무선기기) 주파수는 서로 간섭을 용인하고 허가없이 사 용하는 소출력 용도로서 전 대역에 걸쳐 약 $26 \mathrm{GHz}$ 폭이 사용되고 있다. 최근 $\mathrm{Wi-Fi}$, 리모컨, 하이패스, RFID(radio frequency identification) 등 생활밀착형 서비스로 이용이 확대되고 있다.

표 3. 자가통신 및 비면허 용도 주파수의 활용 특성

Table 3. Application characteristics of spectrums for inhouse telecommunication network and non- licensed wireless device.

\begin{tabular}{|c|c|c|c|}
\hline Usage & Utilization entity & Bandwidth & Cost of use \\
\hline $\begin{array}{c}\text { In-house } \\
\text { telecommunicati } \\
\text { on network }\end{array}$ & $\begin{array}{c}\text { Business, public } \\
\text { institutions, } \\
\text { individuals, etc }\end{array}$ & $15,000 \mathrm{MHz}$ & Not charged \\
\hline $\begin{array}{c}\text { Non-licensed } \\
\text { wireless device }\end{array}$ & Unspecified & $26,300 \mathrm{MHz}$ & Not charged \\
\hline
\end{tabular}

IV. 용도별 주파수의 경제성 평가 최적 대안 제안

각 방법론의 제약조건을 통해 최적 대안을 검토하기에 앞서 본 연구는 '객관성'을 고려한다. 이는 주파수의 경제 적 가치에 대한 논쟁을 최소화하기 위해서는 다양한 이 해관계자가 수용할 수 있으며, 검증이 가능해야 하기 때 문이다. 구체적으로 각 대안을 실증적으로 구현함에 있어 공개된 자료의 활용이 전제되어야 할 것이다.

본 연구는 경매, 이익접근, 벤치마크접근, 기회비용 및 생산함수 접근의 순서로 우선순위를 제안한다. 경매는 활 용 주체의 제시한 지불의사에 기초하므로 주파수의 경제 성을 직접적으로 반영할 뿐만 아니라, 적정성에 대한 논 쟁이 야기될 가능성이 적으므로 최선의 대안으로 고려될 수 있다. 이익접근은 주파수의 활용에 따른 경제적 이익 에 기초하여 직관적 이해가 용이하며, 공개된 자료를 활 용하는 측면에서 객관성이 담보된다. 벤치마크접근의 경 우 거래 자료의 확보가 전제되어야 하는데, 국내의 대부 분 용도의 주파수에 대한 이용대가 부과 사례가 거의 존 재치 않기 때문에 현실화 가능성이 비교적 크지 않다. 기 회비용 또는 생산함수 접근의 경우, 유연한 적용이 가능 하지만, 생산요소 간 대체관계에 대한 시나리오를 구축해 야 하며, 상당한 내부 자료가 요구되는 점에서 활용성이 높지 않을 것으로 판단한다.

그림 1 은 주파수 경제성 평가의 최적 방법론의 도출과 정을 나타낸다. 첫 번째 기준은 경쟁적 수요의 존재 여부 를 파악하는 것이다. 이는 경매의 활용 가능성을 가늠하 기 위한 기준이다. 주파수 활용에 있어 경쟁적 수요가 존 재치 않는 경우, 경매를 실시하기 힘들다. 따라서 경쟁적 수요가 존재하는 용도에 한하여 경매를 실시하고, 그렇지 않다면 다른 방법론을 적용하는 것이 바람직하다12). 두 번째 기준으로 단일 서비스 제공 여부를 확인한다. 이러 한 기준은 이익접근의 적용 가능성을 검토하기 위해 설 정된다. 전술한 바와 같이 이익접근은 재무제표에 기초하 여 추정된다. 따라서 단일 서비스를 제공하는 사업자에 한하여 영업활동 전체에 대한 정보를 포함하는 재무제표 를 활용하여 경제성을 추정할 수 있다. 세 번째 기준은 기

12) 현행 전파법에서도 경쟁적 수요의 존재 여부에 따라 경매의 실시 여부를 판단한다. 


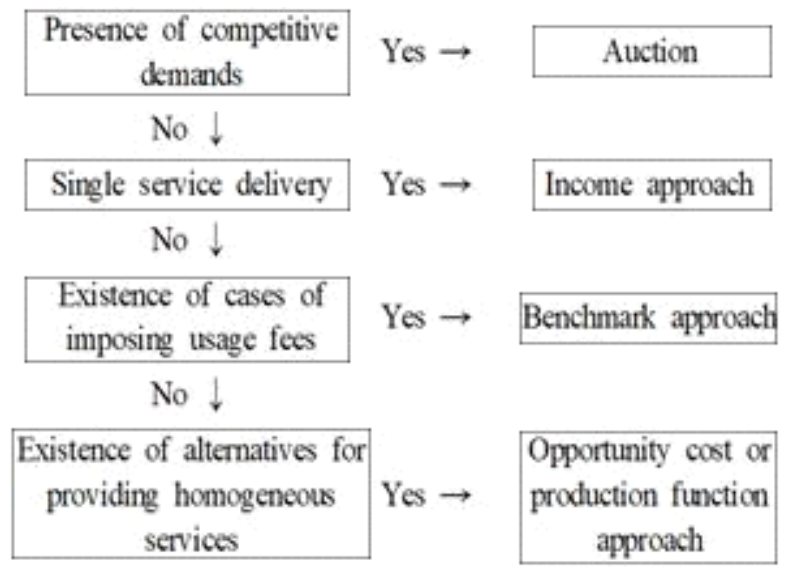

그림 1. 용도별 주파수의 경제성 평가 최적 대안 모색 과정

Fig. 1. The process to find optimal alternatives for estimating the spectrum value by usage.

존 이용대가(할당가격 또는 거래가격) 부과 사례의 존재 를 평가하는 것이다. 이는 벤치마크접근의 적용 가능성을 판단하기 위한 기준이다. 마지막 기준으로 동질적 서비스 를 제공하기 위한 대안의 존재 여부를 파악한다. 이는 기 회비용 또는 생산함수 접근의 적용 가능성을 가늠하기 위한 기준이다. 객관적 대안이 존재할 경우, 이를 실현하 기 위해 수반되는 비용이나, 생산함수의 추정을 통해 대 체성을 평가함으로써 경제성을 추정할 수 있다.

앞선 제안을 거쳐 주요 용도별 주파수의 경제성 평가 대안을 도출한 결과는 표 3에 제시한 바와 같다. 이동통 신의 경우, 다수의 사업자가 시장에 존재하므로 경쟁적 수요에 기초한 경매의 적용이 가능하다. 다만, 최저경쟁 가격 설정에 있어 벤치마크접근이 용이할 것으로 판단되 는데, 이는 $3 \mathrm{G}, 4 \mathrm{G} / \mathrm{LTE}, 5 \mathrm{G}$ 등 다수의 서비스를 제공하기 때문에 이익접근이 어렵기 때문이다. 더불어, 국내 혹은 여타 국가의 다수의 경매 사례가 존재하기 때문에 자의 성을 내포한 기회비용접근을 시도할 필요성이 낮다.

주파수 공용통신의 경우, 이익접근이 적합할 것으로 판단된다. 해당 서비스 시장에는 단일 사업자만이 존재하 므로 경매의 적용이 힘들다. 다만, 단일 서비스만을 제공
하므로 재무제표의 추정을 통한 이익접근이 가능할 것으 로 판단된다. ${ }^{13)}$ 무선데이터통신 역시 주파수 공용통신과 유사한 특성을 보이므로 이익접근이 용이할 것으로 판단 된다. 무선호출 역시 단일 사업자가 단일 서비스를 제공 하고 있다. 하지만 비교적 영세한 사업규모를 가짐에 따 라 재무제표를 확보하기 어렵다.14) 따라서 이익접근을 적 용하기 위한 객관적 자료의 확보가 용이하지 않다. 다만, 무선호출은 주파수 공용통신, 무선데이터와 동일하게 육 상이동 업무로 분류될 수 있으므로 이들 용도에 활용된 주파수와 유사한 경제성을 보유할 것으로 판단된다. 이러 한 논리 하에서 벤치마크 접근이 실현 가능한 대안으로 간주될 수 있다.

국간중계 서비스에 관련하여 연권흠 외 $(2019)^{[10]}$ 는 $\mathrm{M} / \mathrm{W}$ 용도 주파수의 경제성을 대역 이전에 소요되는 기 회비용을 통해 추정한다. 이들 연구에서 M./W 용도 주파 수가 중간 투입물로 활용되므로 이로부터 발생되는 경제 적 이익을 평가하기 힘들며, 거래 자료가 존재치 않아 벤 치마크접근의 적용이 어려움을 제시한다. 본 연구 역시 이러한 주장에 따라 국간중계 용도 주파수에 대한 기회 비용접근이 적절함을 제안한다.

위성 서비스의 경우, 위성체에 대한 대규모의 투자가 선행되기 때문에 할당 이전 특정 대역의 주파수 활용에 대한 계획이 사업자별로 각기 수립될 것으로 판단된다. 따라서 사업자 간 주파수에 대한 경쟁적 수요가 존재한 다고 쉽게 단정하기 어렵다. 주요 사업자의 수익의 대부 분이 주파수 활용에 따른 위성이용료에 기초하므로 이익 접근의 효율적인 대안으로 고려될 수 있다.

자가통신용 주파수는 용도와 특성이 활용 주체별로 상 이하므로, 경쟁적 수요의 존재를 쉽게 예단하기 힘들다. 일반적으로 영업활동의 부수적 지원 역할을 하는데 주파 수가 활용되므로, 경제적 이익에 대한 기여도는 크지 않을 것으로 판단되어, 재무제표를 활용한 이익접근 역시 용이 하지 않다. 더불어, 기존 거래 자료로 쉽게 찾기 힘들다. 따라서 기회비용접근의 적용이 적절할 것으로 판단한다. 비면허 용도 주파수는 본질적으로 활용 주체가 명확하

13) 변희섭 외 $(2019)^{[9]}$ 는 주파수공용통신 용도 주파수의 경제성을 기회비용접근을 통해 평가한다. 이들은 LTE망 임차를 기회비용으로 인식한다.

14) 주식회사 등의 외부감사에 관한 법률에 의하면, 자산, 부채, 종업원 수, 매출액 등을 일정 기준 이상에 해당하는 기업은 외부감사의 대상으로 재무 제표를 작성하여 독립된 외부 감사인에 의한 회계감사를 받아야 한다. 
표 4. 주요 용도별 주파수의 경제성 평가 대안

Table 4. Alternatives for evaluating the spectrurn value by usage.

\begin{tabular}{|c|c|l|}
\hline Category & Usage & \multicolumn{1}{|c|}{ Alternatives } \\
\hline \multirow{4}{*}{$\begin{array}{c}\text { Telecom- } \\
\text { munica- } \\
\text { tions } \\
\text { business }\end{array}$} & Mobile communication & $\begin{array}{c}\text { Auction } \\
\text { Benchmark approach } \\
\text { (reserve price) }\end{array}$ \\
\cline { 2 - 4 } & $\begin{array}{c}\text { Wireless data } \\
\text { communication }\end{array}$ & $\cdot$ Income approach \\
\cline { 2 - 4 } & Radio paging & $\cdot$ Benchmark approach \\
\cline { 2 - 4 } & Satellite & $\cdot$ Income approach \\
\cline { 2 - 4 } & Microwave relay service & $\cdot$ Opportunity cost approach \\
\hline \multicolumn{2}{|c|}{$\begin{array}{l}\text { In-house telecommunication } \\
\text { network }\end{array}$} & $\cdot$ Opportunity cost approach \\
\hline \multicolumn{2}{|c|}{ Non-licensed wireless device } & $\cdot$ Opportunity cost approach \\
\hline
\end{tabular}

지 않으며, 활용에 따른 경제적 이익을 평가하기 힘들다. 따라서 경매, 이익접근의 구현이 어렵다. 그간 이용대가 가 부과되지 않았기 때문에 참고할만한 거래 자료도 거 의 존재치 않는다. 따라서 기회비용접근이 최적 대안으로 고려된다. 관련하여, 김희천 외 (2017) ${ }^{[11]}$ 역시 Wi-Fi 접속 등 비면허 대역 주파수의 경제성을 기회비용접근을 통해 평가될 수 있음을 제안한다(표 4). ${ }^{15)}$

\section{$\mathrm{V}$. 결론 및 시사점}

국내에서 주파수의 경제적 가치 평가에 대한 정책적, 실무적 관심이 고조되는 반면, 이에 대한 대안을 체계적 으로 제시한 연구는 쉽게 찾기 힘들다. 특히, 이론적 정합 성이 높은 대안이 존재하더라도, 실증적 적용 가능성이 담보되지 않을 경우, 현실성이 떨어질 수밖에 없다. 이러 한 관점에서 본 연구는 기존에 제기된 주파수의 경제성 평가 대안들을 검토하고, 국내의 용도별 특성에 적합한 대안을 제안한다. 구체적으로 주요 용도별 주파수의 경제 성 평가 대안으로 이동통신 용도는 경매와 벤치마크접근, 주파수 공용통신, 무선데이터, 위성 용도는 이익 접근, 무 선호출은 벤치마크 접근, 국간중계는 기회비용 접근의 활
용을 제안한다. 더불어, 자가통신 및 비면허 용도 주파수 의 경우, 기회비용 접근이 최적 대안으로 검토될 수 있음 을 제시한다.

본 연구는 주파수의 면허제 시행에 앞서 용도별 경제 성 평가의 방향성을 모색하고, 체계화하는데 기여할 것으 로 기대된다. 특히, 현행 전파법 시행령은 매출액의 기여 도로 주파수의 이용대가를 산정하는데, 이러한 체계를 보 다 정교화하는데 기여할 것으로 평가된다. 면허제 도입으 로 인해 용도별 주파수의 경제성에 대한 기준이 정량화 될 경우, 거시적으로 용도별 주파수 분배에 있어 이용 효 율 개선을 위한 기초자료의 마련이 가능할 것이므로, 본 연구는 이에 대한 선행작업으로도 이해될 수 있다.

한편, 본 연구가 제시한 경제성 평가 방법들의 적용 결 과는 모두 금전적 가치로 산출된다. 따라서 용도가 상이 한 주파수 간 경제성을 비교할 경우에도 활용이 가능하 다. 다만, 상이한 용도로 인해 각기 다른 방법이 적용된 경우 그 가정이 상이하기 때문에 신중한 접근이 필요하 다. 가령, 경매 낙찰가를 통해 도출된 경제성은 주파수 활 용 주체의 지불의사를 반영하는 반면, 이익접근을 통한 경제성은 이를 초과하는 실제 창출한 경제적 이익을 의 미한다.

\section{References}

[1] H. Byun, Y. Kim, K. Yeon, D. Lee, Y. Kim, and Y. Choi, et al., "Measuring the economic value of radio spectrums for fixed and satellite services," Korea Communications Agency, Naju, Jul. 2020.

[2] Minister of Science and ICT, "A complex spectrum utilization scheme is incorporated into a licensing system," Press Releases, Nov. 2019.

[3] H. Byun, Y. Kim, K. Yeon, J. Hong, and D. Kim, "A study on the methodology for estimating economic value of radio spectrums for regional wireless service," Korea Communications Agency, Naju, Dec. 2017.

[4] I. Jeong, J. Yeo, "Status and issues of spectrum auc-

15) 이 연구는 사회후생, 파급효과 등을 통해 경제성을 평가하는 대안도 동시에 제안한다. 
THE JOURNAL OF KOREAN INSTITUTE OF ELECTROMAGNETIC ENGINEERING AND SCIENCE. vol. 32, no. 1, January. 2021.

tions," Korea Information Society Development Institute, Jincheon, Dec. 2011.12.

[5] DotEcon and Aetha, "Spectrum value of $800 \mathrm{MHz}, 1,800$ $\mathrm{MHz}$ and 2.6 GHz: A DotEcon and Aetha report for Ofcom," London, 2012.

[6] Smith-NERA, "Study into the use of spectrum pricing," Radiocommunications Agency, London, 1996.

[7] Indepen, Aegis Systems, Warwick Business School, "An economic study to review spectrum pricing," Indepen, London, 2004.

[8] International Telecommunication Union, "Methodologies for valuation of spectrum," Geneva, 2017.

[9] H. S. Byun, K. H. Yeon, and Y. Kim, "Estimating the

변 희 섭 [한림대학교/조교수]

https://orcid.org/0000-0002-2746-8485

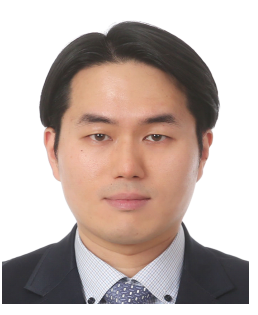

2007년 2월: 한양대학교 ERICA 캠퍼스 경 제학부 (경제학사)

2009년 2월: 한양대학교 응용경제학과 (경 제학석사)

2012년 8월: 고려대학교 경영학과 (경영학 박사)

2015년 2월 현재: 한림대학교 금융재무

학과 조교수

[주 관심분야] 무형자산 가치평가, 주파수 경제성 평가

연 권 흠 [세종기술경제연구소/소장]

https://orcid.org/0000-0002-1104-4290

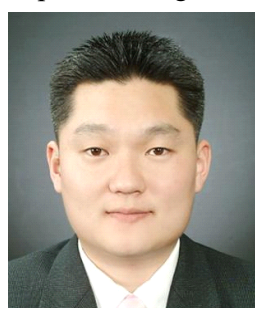

2003년 2월: 한양대학교 ERICA 캠퍼스 경 제학부 (경제학사)

2005년 2월: 한양대학교 응용경제학과 (경 제학석사)

2016년 2월: 한양대학교 응용경제학과 (경 제학박사)

2018년 5월 현재: 세종기술경제연구소

소장

[주 관심분야] 주파수 정책, ICT 산업분석 economic value of radio spectrum for trunked radio system," The Journal of Korean Institute of Electromagnetic Engineering and Science, vol. 30, no. 5, pp. 356-364, May 2019.

[10] K. Yeon, K. Kim, and Y. Kim, "The economic value of the radio spectrum for fixed services, and the proposed reasonable spectrum usage fees," Korean Telecommunications Policy Review, vol. 26, no. 2, pp. 95-121, 2019.

[11] H. Kim, D. Lim, A. Jeong, and I. Kim, "A study on the methodology for estimating the economic value for an unlicensed band frequency," Korea Information Society Development Institute, Jincheon, Oct. 2017.

\section{김 기 원 [한국방송통신전파진흥원/차장]}

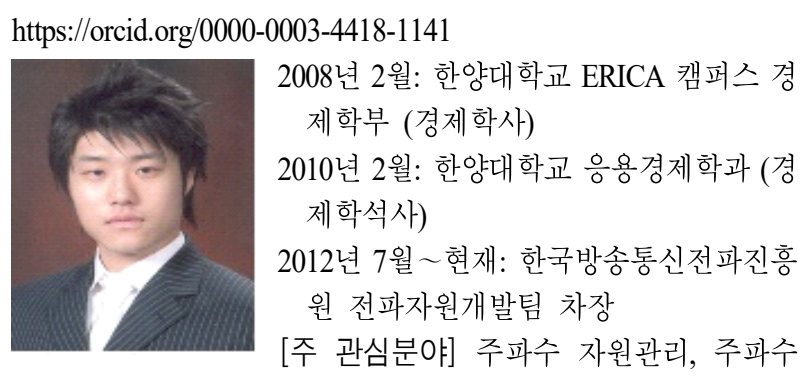

이용효율 평가 